\title{
Occurrence of foliar nitrate reductase activity not induced by nitrate in symbiotic nitrogen-fed black alder (Alnus glutinosa)
}

\author{
S. Benamar ${ }^{1}$, G. Pizelle ${ }^{1}$ and G. Thiéry 2 \\ ${ }^{1}$ Laboratoire de Physiologie Végétale et Forestière, Faculté des Sciences, BP 239, 54506 \\ Vandouvre-lès-Nancy Cedex, and \\ 2Physiologie Végétale, ENSAIA, 54500 Vandœuvre-lès-Nancy, France
}

\section{Introduction}

Black alder (Alnus glutinosa (L.) Gaertn.) acquires nitrogen from its environment by symbiotic nitrogen fixation within its actinorhizas and by uptake of combined nitrogen from the soil solution. $\mathrm{NO}_{3}^{-}$represents the major form of combined nitrogen in alder soils, which possess a high capacity for nitrification (Bollen and Lu, 1968). It is well established that black alder has the ability to reduce $\mathrm{NO}_{3}^{-}$in both roots and leaves (Pizelle and Thiéry, 1974; 1986). The present study was performed on young black alders grown under axenic or non-axenic conditions and supplied with nitrate or nitrate-free nutrient solution. The objectives were to: 1) evaluate the effect of nitrogen source and plant age on leaf nitrate reductase (NR) activity measured in vivo; 2) verify that leaf NR activity was not due to an artifact of microbial origin; 3) examine the relationship between plant growth and leaf NR activity.

\section{Materials and Methods}

Young black alders were grown in a growth chamber; light/dark cycle, temperature and $\mathrm{RH}$ :
$16 / 8 \mathrm{~h}, 25 / 18^{\circ} \mathrm{C}$ and $60 / 80 \%$, respectively; photon flux density: $200 \mu \mathrm{E} \cdot \mathrm{m}^{-2} \cdot \mathrm{h}^{-1}$ from Metalarc Sylvania lamps.

Axenic and non-axenic plants were grown on perlite in test tubes and on a vermiculite-sand mixture $(v / v)$, respectively. Nodulation was obtained, if necessary, by inoculation with a pure Frankia suspension in axenic cultures and with an actinorhizal suspension in non-axenic cultures. The nodulated plants were grown on an $\mathrm{N}$-free solution; $4 \mathrm{mM} \mathrm{NaNO}$ was added to this solution to supply the nitrate-fed plants.

Leaf NR activity was determined as described by Pizelle and Thiéry (1986) with the modification that the concentration of $\mathrm{KNO}_{3}$ was $0.05 \mathrm{M}$ in the incubation medium.

\section{Results}

Effect of nitrogen source and plant age on the leaf NR activity

The nodulated plants grown without combined nitrogen expressed leaf NR activities which were higher than those of the plants supplied with nitrate (Fig. 1). The leaf NR activities of both $N_{2}$-fixing and 
nitrate-fed alders presented great variations between plants and, in one plant, between dates of measurement. In addition, these data show that NR can be active in the leaves of the plants not supplied with nitrate. This NR activity, not induced by nitrate was termed 'constitutive' NR.

Blacquière and Troelstra (1986) postulated that leaf NR activity measured in vivo in alder might be of microbial origin. This hypothesis was tested by using plants in axenic culture.

Leaf NR activity of plants in axenic culture

The axenic leaf tissues from nodulated or non-nodulated alders grown with or without nitrate expressed notable NR activity (Table I). These findings indicate that the NR activity originates in leaf tissues, and not in microbial phyllosphere, as suggest- ed by Blacquière and Troelstra (1986). From these results, we conclude that the leaves of A. glutinosa present a constitutive NR activity not induced by nitrate.

Comparison of the constitutive leaf NR activity in symbiotic nitrogen-fed black alders

In order to determine whether the variations of leaf NR activity previously observed (Fig. 1) were a coincidence or whether the plants could be distinguished from each other by the level of their enzyme activity, we followed the individual leaf NR activities of symbiotic nitrogen-fed alders for several weeks. The data presented in Table II allowed us to distinguish at least 2 groups of plants having significantly different levels of leaf NR activity: one group having low enzyme activity (plants 1-3) and one having high enzyme activity (plants 9-12).

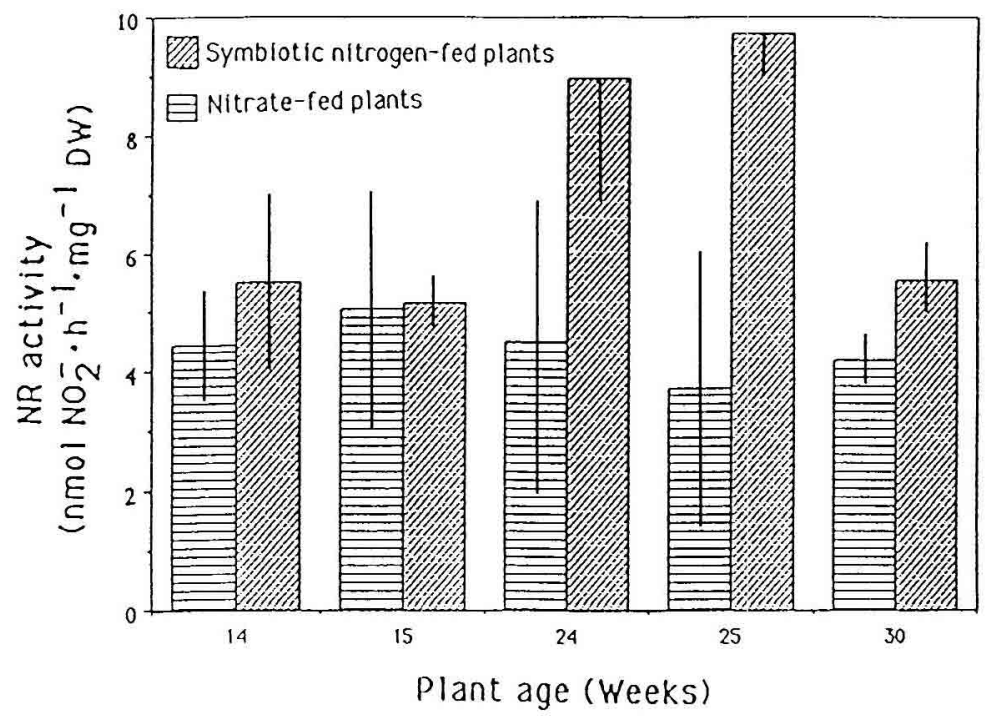

Fig. 1. Effect of nitrogen source and plant age on the in vivo leaf NR activity of young alders. Means of 4 samples \pm $\mathrm{SE}$. 
Table I. In vivo leaf NR activity and growth of 16 wk old alders supplied with $4 \mathrm{mM} \mathrm{NaNO}$ and/or symbiotic nitrogen in axenic culture.

\begin{tabular}{|c|c|c|c|}
\hline \multirow[t]{2}{*}{ Nitrogen nutrition } & \multirow{2}{*}{$\begin{array}{l}\text { Foliar NR activity } \\
\left.\text { (nmol NO } \mathrm{NO}_{2}^{-\cdot m g^{-1}} D W \cdot h^{-1}\right)\end{array}$} & \multicolumn{2}{|c|}{ Growth (mg DW.plant ${ }^{-1}$ ) } \\
\hline & & shoots & roots \\
\hline $\begin{array}{l}\text { Without nitrogen } \\
\text { (control) }\end{array}$ & $3.08 \pm 0.28$ & 15.6 & 19.9 \\
\hline $\begin{array}{l}\text { Symbiotic } \\
\text { Nitrate }^{\mathrm{a}}\end{array}$ & $\begin{array}{l}5.25 \pm 1.20 \\
5.21 \pm 0.54\end{array}$ & $\begin{array}{l}105.3 \\
100.8\end{array}$ & $\begin{array}{l}39.9 \\
60.0\end{array}$ \\
\hline Symbiotic + nitrate ${ }^{a}$ & $3.59 \pm 0.20$ & 149.3 & 47.3 \\
\hline
\end{tabular}

a $4 \mathrm{mM} \mathrm{NaNO}_{3}$.

Means of 4 samples \pm SE.

Table II. Comparison of the in vivo leaf NR activity in nodulated alders starved of combined nitrogen.

\begin{tabular}{|c|c|c|}
\hline $\begin{array}{l}\text { Plant } \\
\text { no. }\end{array}$ & $\begin{array}{l}\text { Foliar NR activity } \\
\left(n m o l ~ N O_{2}^{-} \cdot m g^{-1} D W \cdot r^{-1}\right)\end{array}$ & $\begin{array}{l}\text { Dry weight } \\
\text { (g) }\end{array}$ \\
\hline 1 & $5.9 \pm 1.0 \mathrm{a}$ & 1.41 \\
\hline 2 & $7.5 \pm 0.4 \mathrm{ab}$ & 2.72 \\
\hline 3 & $8.0 \pm 1.4 \mathrm{abc}$ & 1.17 \\
\hline 4 & $8.5 \pm 1.4 b c$ & 6.70 \\
\hline 5 & $8.6 \pm 1.4 b c$ & 2.70 \\
\hline 6 & $8.8 \pm 1.6 \mathrm{bcd}$ & 0.59 \\
\hline 7 & $10.2 \pm 1,6$ cde & 5.49 \\
\hline 8 & $10.3 \pm 0,9 \mathrm{cde}$ & 7.71 \\
\hline 9 & $11.2 \pm 0.8 \mathrm{def}$ & 6.57 \\
\hline 10 & $12.2 \pm 1.0$ ef & 9.35 \\
\hline 11 & $12.9 \pm 1.1 \mathrm{f}$ & 6.71 \\
\hline 12 & $13.7 \pm 1.7 f$ & 13.38 \\
\hline
\end{tabular}

Each value is the mean of 7 assays spread over 10 wk on one plant. Means followed by the same letters are not significantly different at $P \leq 0.05$.

The variations of the NR activity of each group (Fig. 2) show that the means of the enzyme activities of the 1st and 2nd groups are consistently lower and higher, respectively, than that of the 12 plants assayed. Thus young black alders could be distinguished by the level of their constitutive leaf NR activity. Hence, the question arose whether any relationship exists between this enzyme activity and plant growth.
Relationship between constitutive leaf NR activity and plant growth

The data given in Table II show a high correlation between growth and mean NR activity in the leaves of each plant ( $r=0.841, n=12, P<0.001)$. In addition, this correlation increased with plant age between 16 and 24 wk (data not shown). Such a correlation has been reported in 


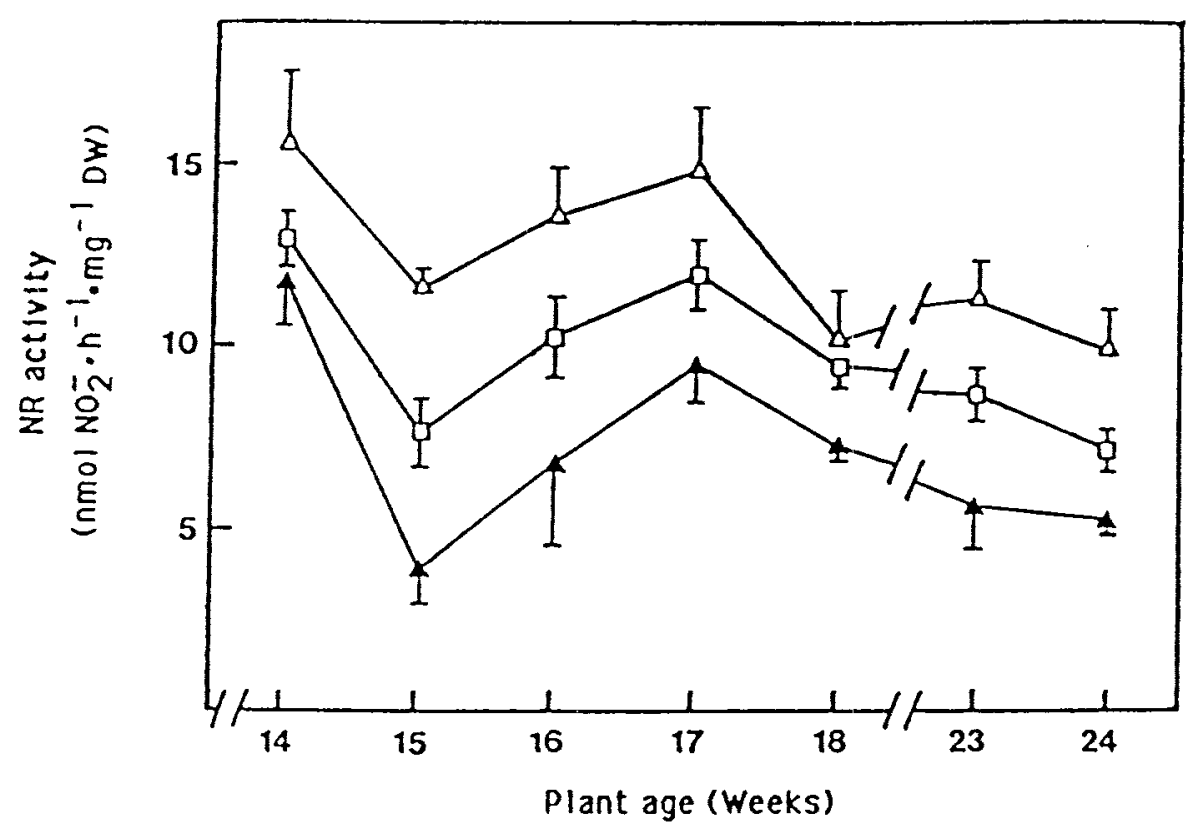

Fig. 2. Variation of the in vivo leaf NR activity (means \pm SE) over 10 wk in the plants presented in Table II grouped according to the level of their enzyme activity. $\Delta$ : group of low activity (plants $1-3$ ); $\Delta$ : group of high activity (plants 9-12); $\square$ : all 12 plants in Table II.

herbaceous (Lee and Stewart, 1978) and young woody plants (Lee et al., 1985) supplied with nitrate. However, in the case of symbiotic nitrogen-fed $A$. glutinosa of the present study, the leaf NR activity was correlated with the plant growth even if it did not contribute to the nitrogen nutrition of the plant.

\section{Conclusion}

Our results show that the leaves of Alnus glutinosa have a constitutive NR activity not induced by nitrate nutrition and not due to an artifact of microbial origin. But it is difficult to specify the role of this enzyme activity. Diaphorase activity (Guerrero et al., 1981), iron nutrition (Smarelli and Castignetti, 1986), intervention in the case of unusual nitrate flux, are hypothetical roles which might be attributed to this NR activity. Regardless of its yet unknown role(s), the constitutive NR activity of the leaves of $A$. glutinosa must have a physiological significance, since its level is positively correlated with plant growth. Hence, this enzymatic activity could be a good indicator of the growth potential of young black alders.

\section{References}

Blacquière T. \& Troelstra S.R. (1986) Nitrate reductase activity in leaves and roots of Alnus glutinosa (L.) Gaertner. Plant Soil 95, 301-313

Bollen W.B. \& Lu K.C. (1968) Nitrogen transformation in soil beneath red alders and conifers. In: Biology of Alder. (Trappe J.M., Franklin J.F., 
Tarrant R. \& Hansen G.M., eds.), Forest Service-USDA, Oregon, pp. 141-148

Guerrero M.G., Vega J.M. \& Losada M. (1981) The assimilatory nitrate reducing system and its regulation. Annu. Rev. Plant Physiol. 32, 169204

Lee D.K., Kim G.T. \& Lee K.J. (1985) Variations in peroxidase and nitrate reductase activities and growth of Populus alba $\times$ Populus glandulosa $F_{1}$ clones. J. Korean For. Soc. 70, 63-71

Lee J.A. \& Stewart G.R. (1978) Ecological aspects of nitrogen assimilation. Adv. Bot. Res. $6,1-43$
Pizelle G. \& Thiéry G. (1974) Réduction des nitrates par les feuilles, les racines et les nodules d'aune glutineux (Alnus glutinosa L. Gaertn.) C.R. Acad. Sci. Paris, Sér. D. 279, 1535-1537

Pizelle G. \& Thiéry G. (1986) Reduction of nitrate in the perennial tissues of aerial parts of Alnus glutinosa. Physiol. Plant. 68, 347-352

Smarelli J. Jr. \& Castignetti D. (1986) Iron acquisition by plants: the reduction of ferrisiderophores by higher plants NADH:nitrate reductase. Biochim. Biophys. Acta 882, 337-342 